\title{
UNIFIKACJA, MODERNIZACJA, OPRESJA. PRZEMIANY APARATU ADMINISTRACYJNEGO II RZECZYPOSPOLITEJ
}

\author{
Janusz Mierzwa
}

(D) http://orcid.org/0000-0003-0534-1958

Uniwersytet Jagielloński w Krakowie

\author{
ABSTRACT \\ UNIFICATION, MODERNIZATION, OPPRESSION: CHANGES OF THE \\ ADMINISTRATION OF THE SECOND POLISH REPUBLIC
}

The creation of Polish public administration after regaining independence was characterized by two attributes - continuation (in the legal and organizational aspect) and novelty (personal aspect). At the beginning the process of modernization was uncoordinated, but this changed after the coup d'état. The Great Depression interfered with it, but after 1935 reforms proceeded in the same direction, for the most part. Similarly, the unification process was uncoordinated, gradually becoming more structured and rapid after 1926. Finally, serious changes of voivodship borders were made just before WWII. At the same time, we can observe the growing oppression of the administration, even though it was already detectable in the democratic period, it became stronger and more widespread when Józef Piłsudski's camp took power. It manifested through physical violence, censorship, and the surveillance of opposition. It reflected not only the ways of the undemocratic government but was also associated with the brutalization of social habits and with the threats to internal security.

Keywords: Second Polish Republic, administration, self-government, modernization, unification.

Słowa kluczowe: II Rzeczpospolita, administracja, samorząd terytorialny, modernizacja, unifikacja.

Zastanawiając się nad drogą, jaką przeszła administracja publiczna w ciągu 20 lat Polski niepodległej, starałem się znaleźć słowa najlepiej oddające towarzyszącą jej w tym czasie transformację. Pojęcia te nie są oczywiste, choć część z nich w ostatnich latach coraz częściej jest wykorzystywana do opisania zjawisk i procesów, które się dokonały w dwudziestoleciu. Hasła unifikacji czy modernizacji szczególnie często padały i będą padać, gdy mówimy o państwie; samo pojęcie modernizacji znajdzie też odniesienie do omawianych w innych artykułach zagadnień społecznych. W odniesieniu do problemu opresyjności systemu administracyjnego II RP nie 
chodzi o to, by obnażać Polskę niepodległą, ale raczej by pamiętać, że nie było to państwo przyjazne obywatelowi, bo nie obywatel był w nim na pierwszym miejscu (przekonanie to zyskało sankcję konstytucyjną w 1935 r.). Co ważne, wszystkie te trzy procesy były od siebie współzależne.

Tworzone od 1918 roku państwo polskie stanęło wobec wielu bardzo poważnych wyzwań, takich jak organizacja struktur państwowych, walka o granice czy odbudowa gospodarki. Dwa z nich miały jednak charakter długofalowy - unifikacja i modernizacja. Rok 1939 stanowił ich zamknięcie w obrębie struktury, jaką była II RP, ale w zmienionych uwarunkowaniach politycznych niektóre z nich pozostały istotne po 1945 roku.

W zasadzie zacząć należałoby od stwierdzenia Przemysława Olstowskiego, że zrozumienie najnowszej historii Polski nie jest możliwe bez prześledzenia tego, co się działo w wieku XIX i XX, a zatem w czasie budowania nowoczesnych narodów i społeczeństw ${ }^{1}$. W kontekście podjętego zagadnienia administracji oznacza to, że cały okres, gdy państwa i społeczeństwa przechodziły intensywne procesy modernizacyjne oraz kształtowały własne modele biurokratyczne, ziemie polskie znajdowały się pod zaborami. W efekcie tego Polska w momencie odzyskania niepodległości nie miała wypracowanych własnych rozwiązań, a musiała się opierać na zaczerpniętych od zaborców, i to one podlegały modyfikacjom oraz procesom dostosowawczym do lokalnej specyfiki.

W przypadku licznych zagadnień byliśmy wręcz zdani na dorobek zaborców w poszczególnych obszarach. Jest to problem nie tylko spuścizny w zakresie stanu prawnego i konieczności wpisania nowego państwa jako kontynuatora (z formalnego punktu widzenia) poprzednich reżimów, ale także wyzwanie w dziedzinie polityki personalnej czy organizacji administracji. Na dobrą sprawę to właśnie ci, którzy znaleźli się w aparacie administracyjnym pierwszych miesięcy i lat niepodległości, jako fachowcy decydowali o przyjętym modelu struktury.

Kluczowe znaczenie miał w tym aspekcie fakt doraźności działań podejmowanych od listopada 1918 roku. Proces przygotowania przez TRS i RR kadr (spisy potencjalnych urzędników, edukacja teoretyczna i praktyczna nowych) nie został zakończony. Przejmowanie władzy zarówno w Warszawie czy Poznaniu, Krakowie, jak i na prowincji odbywało się nie wedle z góry opracowanego planu, lecz ad hoc, w reakcji na wydarzenia, które w istocie zaskakiwały. Odzyskanie niepodległości wymusiło tworzenie nowych struktur tam, gdzie nie zostały one odziedziczone po zaborcach czy okupantach, ale także wypełnienie istniejących nowymi polskimi urzędnikami². Zazwyczaj niefachowymi, czasami z wykorzystaniem lokalnych elit,

${ }^{1}$ P. Olstowski, O potrzebach badań nad procesami modernizacji spotecznej na ziemiach Polski zachodniej w XIX i w poczatkach XX wieku [w:] $W$ kręgu dwóch kultur. Spoleczeństwo polskich ziem zachodnich wXIXi XX stuleciu, red. S. Wierzchosławski, A. Niewęgłowska, T. Krzemiński, Torun 2017, s. 11.

${ }^{2}$ Nie dotyczyło to Galicji Zachodniej, gdzie zmiany miały charakter jednostkowy, a w Królestwie Polskim działów takich jak sprawiedliwość czy szkolnictwo. W odniesieniu do administracji ogólnej kontynuowano współpracę np. z byłymi komisarzami cywilnymi z okupacji austriackiej, ale w większości pozostałych przypadków zatrudniano „z zewnątrz” Polaków. 
zwykle bez cenzusu wykształcenia. Wszystko to oznaczało przyjęcie przez młode państwo bez przygotowania sporego balastu, z którym borykać się będzie musiało do 1939 roku. Jeszcze większym problemem było, również niepoprzedzone analizą, przyjęcie systemu biurowości w wydaniu austriackim. Wpływ na to mieli przede wszystkim byli ck urzędnicy, którzy szczególnie intensywnie w dobie rządów Paderewskiego, a w MSW - Stanisława Wojciechowskiego - zaludnili Zarząd Centralny tego resortu ${ }^{3}$, by implementować rozwiązania najlepiej im w praktyce znane ${ }^{4}$. Oznaczało to przyjęcie austriackiego modelu biurokratycznego ${ }^{5}$. Należy też dodać rozszerzanie sfery aktywności państwa przejawiające się między innymi wzmożeniem legislacyjnym dokonywanym na organizmie, który de facto od samego początku nie wzrastał w sposób w pełni kontrolowany.

Już powyższe, ważne, ale tylko wybrane zagadnienia, oddają skalę problemów, przed jakimi stali ci, którzy mieli tę administrację reformować. Okres II RP w zakresie aparatu administracyjnego to bowiem czas procesów dokonujących się w biegu i pod presją trudnych uwarunkowań gospodarczych.

Zarysowując pojęcie modernizacji, które w odniesieniu do dokonujących się w okresie II RP procesów pojawia się coraz częściej, mamy na myśli przede wszystkim unowocześnianie i usprawnianie aparatu administracyjnego organizowanego na ziemiach polskich. Jednocześnie będą się w nim mieściły działania zmierzające do wypracowania własnego modelu organizacji wewnętrznej państwa. W tym drugim aspekcie wiąże się to najczęściej z wprowadzaniem modyfikacji do rozwiązań odziedziczonych po zaborcach.

W pierwszych latach niepodległości działania modernizacyjne miały charakter dość wyrywkowy. Wprowadzano instrukcje, regulaminy, ale bardziej pod wpływem potrzeby chwili niż szerszego planu. Jest to rzecz jasna zrozumiałe, biorąc pod uwagę wyzwania czasu walki o granicę. W późniejszych latach zmiany przychodziły stopniowo. W większym stopniu zwracano na przykład uwagę, by działania podejmowane przez urzędników były osadzone w konkretnych przepisach. Niejednokrotnie wymuszało to na władzach centralnych wprowadzanie w miejsce zwyczaju skodyfikowanych norm, jak to się działo choćby w odniesieniu do zasad wykorzystywania przez urzędników do celów prywatnych mienia państwowego i komunalnego. Weryfikowano pod względem fachowym kadry, ale, jak się wydaje, nie dość konsekwentnie - $\mathrm{w}$ istocie przez palce patrzono na przykład na łamanie niektórych przepisów antykorupcyjnych. Trudno też mówić o planowej działalności szkoleniowej. Bez wątpienia natomiast włożono duży wysiłek chociażby w działania zmierzające

${ }^{3}$ W. Wit kow sk i, Historia administracji w Polsce 1764-1989, Warszawa 2012, s. 222; J. Malec, D. Malec, Historia administracji i myśli administracyjnej, Kraków 2003, s. 176; J. Mi erzw a, Wkład Galicji w niepodległość Polski [w:] Drogi do niepodlegtości narodów Europy Wschodniej 1914-1921, red. D. Michaluk, Ciechanowiec 2018, s. 30-31.

${ }^{4}$ Ale w ostatnich latach przed wojną borykające się z coraz poważniejszym problemem niedrożności. Por. szerzej: A. Dziadzio, M. Mataniak, Namiestnictwo galicyjskie (1854-1914). Organizacja i zadania, „Krakowskie Studia z Historii Państwa i Prawa” 2018, nr 1, s. 137-167.

${ }^{5}$ R. Hausner, Pierwsze dwudziestolecie administracji spraw wewnętrznych, Warszawa 1939, s. $89-90$. 
do ustalenia staży pracy i uprawnień emerytalnych (co biorąc pod uwagę wydarzenia wojenne i rewolucje w Rosji, nie było rzeczą prostą).

Bez wątpienia momentem przełomowym w zakresie modernizacji były wypadki majowe. Władzę przejął obóz piłsudczykowski, ale także sympatyzujący z nim technokraci stojący na stanowisku, że nastąpił moment przyspieszenia w usprawnieniu funkcjonowania państwa. Oznaczało to nie tylko czystkę w aparacie administracyjnym (przeprowadzoną z większą ostrożnością niż powszechnie się wydaje), ale zmiana nastąpiła także w zakresie nastawienia administracji. Wszak to od października 1926 roku nowy minister spraw wewnętrznych Sławoj Składkowski zaczął nakłaniać urzędników do punktualnego otwierania urzędów czy dostosowania godzin pracy do potrzeb zjeżdżających na targi chłopów, a nie własnej wygody. Okres po przewrocie majowym służył większej systematyzacji procesów zarówno w obszarze rekrutacji, jak i podnoszenia kwalifikacji urzędników. Zwracano uwagę na kwestię samodoskonalenia (dostęp do aktualnych aktów prawnych, literatury przedmiotu, organizację wewnętrznych szkoleń), póki sytuacja budżetowa na to pozwalała, organizowano kursy dla starostów, ale także zachęcano do udziału w zewnętrznych przedsięwzięciach (np. organizowanych przez Instytut Naukowej Organizacji i Kierownictwa przy Muzeum Przemysłu i Rolnictwa w Warszawie). Przebudowie na bardziej wydajną uległy także struktury centrali MSW. W jej efekcie doszło do scalenia spraw organizacyjnych i udrożnienia kontaktu z urzędami wojewódzkimi ${ }^{6}$.

Zwrócić należy uwagę, że i do administracji odnosiło się stwierdzenie, iż sukcesy Polski na skalę europejską były limitowane możliwościami ekonomicznymi i osiągano je głównie w obszarach, które nie wymagały sporych środków finansowych. Ta teza będzie miała przełożenie na tempo zmian w zakresie unifikacji, o czym niżej, ale także na zasięg procesów modernizacyjnych. Choć w wymiarze budownictwa publicznego przy wznoszeniu gmachów urzędów wojewódzkich lub starostw sięgano po architekturę modernistyczną, ograniczenia budżetowe nader często powodowały, że wdrażano nowoczesne metody zarządzania w budynkach niespełniających norm sanitarnych. Z mniejszym nasileniem w okresie kryzysu, ale modernizacji podlegał inwentarz biurowy, maszyny do pisania, urzędy podłączano do sieci telefonicznej. Czasami, rzecz jasna, w tej modernizacji posuwano się zbyt daleko, wymieniając powozy na samochody, tam gdzie powiaty nie dysponowały odpowiednią siecią dróg.

$\mathrm{Z}$ drugiej strony można na modernizację spojrzeć przez pryzmat ekonomizacji procesów zarządczych. Od grudnia 1926 roku postępował proces unifikacji formularzy urzędowych; w styczniu 1935 roku wprowadzono system ich centralnego zamawiania. Pozwalało to na oszczędzenie czasu urzędnika, pieniędzy na odrębne zamówienia, ale było także wyrazem ujednolicania zasad i reguł w skali całego państwa (podobną funkcję pełniły też pieczęcie urzędowe). W latach 20. przejmowanie urzędów odbywało się czasami protokolarnie, a czasami bez poświadczenia przejętego stanu majątkowego (jedynie za pokwitowaniem wojewodzie lub ministrowi, że od tego dnia starosta przejmuje odpowiedzialność za powiat). W latach 30., szczególnie w drugiej ich połowie, normą było sporządzanie protokołów zdawczo-odbiorczych

${ }^{6}$ R. Hausner, op. cit., s. 46-47. 
zawierających inwentarz ${ }^{7}$. Trudno traktować to inaczej jak w kategoriach coraz większej troski o majątek publiczny (większej niż niejednokrotnie współcześnie). Również tak promowana przez rządzących po 1926 roku dekoncentracja, czyli przenoszenie kompetencji ze szczebla centralnego na wojewódzki czy powiatowy (ale w ramach administracji rządowej), to praktycyzm oraz oszczędność czasu urzędników i pieniędzy publicznych. Ministerstwo Spraw Wewnętrznych w ten sposób kompensowało stale zwiększający się zakres zadań przy jednoczesnym spadku liczby urzędników ${ }^{8}$.

Warto podkreślić, że większość z omawianych procesów zaszła „po burzy”, od 1935 roku. Uporanie się z kryzysem gospodarczym pozwoliło na planowość podejmowanych działań, bez konieczności oglądania się na przymus oszczędnościowy. Częścią procesu porządkowania aparatu administracyjnego było wprowadzenie w 1937 roku nowych zasad kwalifikowania urzędników ${ }^{9}$. Formularze zostały zunifikowane; pozwalały na wielowymiarową ocenę funkcjonariuszy, ale jednocześnie wypełnienie ich nie pochłaniało zbyt wiele czasu. Wszystko to miało ułatwić powrót do normalności - rozwiązań implementowanych przed przewrotem, a zarzuconych po 1926 roku jako utrudniających opanowanie przez piłsudczyków administracji. To był zresztą też czas, gdy w coraz większym stopniu stanowiska kierownicze na różnych szczeblach administracji przejmowały osoby dojrzewające już w warunkach wolnej Polski.

Istotnym elementem procesów modernizacyjnych było także absorbowanie na polski grunt rozwiązań zachodnich. Chodziło tu nie tyle o bezmyślne przeszczepianie obcych polskiej specyfice rozwiązań, ile raczej szukanie tych nadających się do optymalnego wykorzystania w Polsce. Temu służyło wysyłanie urzędników MSW do przeprowadzenia prac studialnych nad zachodnioeuropejskimi systemami administracyjnymi, głównie w ramach prac Komisji ds. Usprawnienia Administracji.

Procesy modernizacji i unifikacji współwystępowały, wzajemnie się przenikały, były od siebie współzależne. Unifikacja była, jak się wydaje, wyzwaniem wcześniej uświadomionym - zanim Rzeczpospolita powstała, polskie elity zdawały sobie sprawę z konieczności jak najszybszego zszycia trzech zaborów, zatarcia dotychczasowych granic i podziałów, odbudowy wspólnoty opartej na bycie państwowym. W pierwszych latach niepodległości problem podziału administracyjnego stanowił raczej przedmiot dyskusji niż praktycznych działań - były w tym czasie sprawy ważniejsze i pilniejsze, choć już od 1919 roku rozwiązania wprowadzane zrazu na terenie Królestwa Polskiego (np. wprowadzenie dwuinstancyjnej administracji ogólnej) upowszechniano także na obszarze pozostałych zaborów. Proces ten kontynuowano w następnych latach, ale jego dynamika była stosunkowo niewielka i koncentrowała się głównie na dyskusjach w parlamencie (nie bardzo nawet można powiedzieć, że procentujących konkretnymi rozwiązaniami w przyszłości).

${ }^{7}$ Dokładność, szczegółowość, ale także posługiwanie się formularzami widoczne jest również w obszarze wykonywania nadzoru nad jednostkami samorządu terytorialnego. Por. też: J. Mierzwa, Starostowie Polski międzywojennej. Portret zbiorowy, Kraków 2012, s. 239-240.

${ }^{8}$ R. Hausner, op. cit., s. 134.

9 „Dziennik Ustaw Rzeczypospolitej Polskiej” 1937, nr 55, poz. 429. 
Zmiany przybrały na sile po przewrocie majowym. W tym obszarze kluczowe znaczenie miało tu rozporządzenie Prezydenta RP ze stycznia 1928 roku o organizacji i zakresie działania władz administracji ogólnej. Wprowadzane przez nie zmiany w zakresie nazewnictwa i kompetencji w sposób generalny ujednolicały struktury w II RP, doprowadzając na przykład do powstania na Kresach Wschodnich wcześniej tam nieistniejącego surogatu samorządu wojewódzkiego, jakim były Rada i Wydział Wojewódzki. Występujące jeszcze, przede wszystkim w województwach zachodnich, odmienności były usuwane już w latach 30 ., ale nie były to korekty fundamentalne ${ }^{10}$.

Przebudowa struktur wiążąca się przede wszystkim z upodobnieniem wielkości powiatów (łączenie w byłym zaborze pruskim i austriackim, ewentualne dzielenie na Kresach Wschodnich) była procesem nieśmiało zapoczątkowanym już w latach 20., ale z zasadniczymi zmianami mamy do czynienia w 1932 roku. I wtedy dodatkowym impulsem do działań były oszczędności w kosztach utrzymania aparatu administracyjnego. Proces ten nie został dokończony, a i chyba nie był możliwy do pełnego przeprowadzenia, jako warunkowany istotnymi różnicami w rozwoju społeczno-gospodarczym ${ }^{11}$.

Zmiany w zakresie aparatu administracyjnego dotyczyły także samego MSW. W niedługim czasie powołano do życia odrębną sekcję prawno-opiniodawczą z referatami odpowiedzialnymi za poszczególne dzielnice. Istotne znaczenie w procesie zastępowania ustawodawstwa zaborczego jednolitym prawem krajowym w zakresie spraw wewnętrznych miały przede wszystkim wydawane od 1926 roku rozporządzenia Prezydenta ${ }^{12}$. Proces unifikacji wiązał się również z bardzo częstymi zmianami w strukturach organizacyjnych MSW. Jednym z jej owoców była przeprowadzona w 1935 roku reorganizacja inspekcji w MSW, co wkrótce zaowocowało wysypem postępowań karnych i dyscyplinarnych urzędników mających problem z zarządzaniem groszem publicznym ${ }^{13}$.

Podobnie jak w przypadku wspomnianych działań modernizacyjnych, także unifikacja miała istotny aspekt oszczędnościowy. W tych kategoriach należy rozważać przeprowadzone w początkach lat 30. ujednolicanie struktur urzędów wojewódzkich i starostw, zazwyczaj prowadzące do konsolidacji komórek, a zatem i spadku zatrudnienia ${ }^{14}$, a także przejście całości administracji ogólnej na kancelarie działające w systemie bezdziennikowym.

Za swoistą miarę postępów procesu unifikacji kraju (nie tylko w obszarze funkcjonowania administracji) bez wątpienia możemy uznać przenoszenie powiatów między

${ }^{10}$ R. Hausner, op. cit., s. 72-74, 91.

${ }_{11}$ A.J. Mi $1 \mathrm{c}$ c r e k, Podziały terytorialno-administracyjne II Rzeczypospolitej w zakresie administracji zespolonej, Warszawa 2008, s. 65.

12 R. Hausner, op. cit., s. 23-24.

13 J. Mierzwa, Starostowie..., s. 401-411; J. Mierzwa, Wotyński uktad korupcyjny na tle przestępczości urzędniczej w Drugiej Rzeczypospolitej [w:] Margines społeczny Drugiej Rzeczpospolitej, red. nauk. M. Ro d a k, Warszawa 2013, s. 85-102; P. Olstow ski, Procesy,,starościńskie” wwojewództwie pomorskim w latach 1936-1937. Polityka obozu rzadzacego i niejawne mechanizmy władzy na szczeblu powiatu w pierwszej połowie lat trzydziestych w świetle kilku procesów karnych, Warszawa 2014.

${ }^{14}$ W. Kozy ra, Polityka administracyjna ministrów spraw wewnętrznych Rzeczypospolitej Polskiej w latach 1918-1939, Lublin 2009, s. 497-498. 
województwami, ponad granicami dotychczasowych zaborów. Operacja ta wymagała względnego wyrównania różnic $\mathrm{w}$ porządku prawnym pomiędzy poszczególnymi zaborami bądź przyjęcia rozwiązań jednolitych dla całego kraju. Choć istotnym krokiem w tym kierunku były na przykład trzy rozporządzenia Prezydenta z 1928 roku o postępowaniu administracyjnym, przymusowym i karno-administracyjnym, to do „wymiany powiatów” doszło dopiero przed wybuchem II wojny światowej, w latach 1937-1938. Wiązały się one przede wszystkim z przeniesieniem powiatów z byłej Kongresówki do województw poznańskiego i pomorskiego ${ }^{15}$.

Choć opresyjność administracji II RP kojarzymy przede wszystkim ze zmienioną po przewrocie majowym formą rządów, to problem ten ma szerszy aspekt. Znawca problematyki i jednocześnie uczestnik wydarzeń zaznaczał, że gwałtowne poszerzenie sfery działalności „policyjnej” państwa po I wojnie światowej było efektem zarówno zagrożeń dla ładu wewnętrznego, jak i konieczności ,popierania przez państwo twórczych wysiłków obywateli" ${ }^{16}$. W części przypadków opresyjność biurokracji miała charakter reaktywny na brutalizację postaw społecznych, typową dla pierwszej połowy XX wieku. Czas Wielkiej Wojny spowodował obniżenie standardów moralnych w społeczeństwie, a chaos pierwszych lat powojennych i obecność bolszewików przyczyniły się do powstania w społecznościach kresowych przekonania o tymczasowości polskiej obecności na tym terenie. W tej sytuacji państwo musiało pokazać miejscowym, kogo mają słuchać, i że jeżeli władza wydaje polecenia, to należy je wykonać ${ }^{17}$.

I choć widocznym przejawem opresji mogą być obrazki takie jak aresztowania brzeskie, Bereza Kartuska czy strajki chłopskie w latach 30., to pamiętać należy, że w 1923 roku premier Witos nie miał obiekcji przed wysłaniem na krakowskich robotników wojska ${ }^{18}$. Również instytucja tzw. świadectw moralności miała dłuższy rodowód niż władza obozu piłsudczykowskiego, który twórczo (i logicznie) wzbogacił ich tworzenie o materiał zawarty w kartotekach wybitnych działaczy politycznych i społecznych. Jest jednak widoczna fundamentalna zmiana podejścia przed- i pomajowego MSW do tego, co w funkcjonowaniu społeczeństwa je interesuje - pierwotnie jedynie to, co stanowiło zagrożenie dla bezpieczeństwa państwa, po 1926 roku całość życia społeczno-politycznego.

Pamiętać wreszcie należy, że w ocenie opresyjności państwa zawsze dominuje opinia o funkcjonowaniu struktur odpowiedzialnych za zapewnienie bezpieczeństwa publicznego. Nie inaczej rzecz się ma, jeśli idzie o II RP. Krytykować można takie czy inne działania policji, ale zazwyczaj były one efektem bezpośrednich rozkazów starosty czy wojewody. To wszystko było elementem negatywnego wizerunku PP, a nieco wybielało obraz administracji. Znalazło to wyraz na przykład w wystąpieniu Adama Ciołkosza definiującego pobrzeski system rządów przez czerwony ołówek

${ }^{15}$ R. Hausner, op. cit., s. 59.

${ }^{16}$ Ibidem, s. 30.

${ }^{17}$ Zwrócić należy uwagę, że takie argumenty podnosił Piłsudski jako uzasadnienie pacyfikacji Galicji Wschodniej w 1930 r.

${ }_{18} \mathrm{~W}$. Witos, Moje wspomnienia, cz. II, do druku przygotowali i przypisami opatrzyli E. Karc zewski, J.R. Szaflik, Warszawa 1990, s. 233. 
cenzora, białą pałkę policjanta i sądy doraźne ${ }^{19}$. Zestawienie to nie jest do końca sprawiedliwe - wszak sporządził je nie dość, że polityk opozycji, to jeszcze doświadczony 10-tygodniowym pobytem w więzieniu brzeskim pod specyficzną opieką Wacława Kostka-Biernackiego. Niemniej refleksja nad nim jednoznacznie prowokuje do konstatacji, że system ten cały czas ewoluował coraz bardziej w zakresie opresyjności. Skala ingerencji cenzorskich z czasem staje się tak duża, że w drugiej połowie lat 30. nie wystarcza odpowiednia część w comiesięcznym sprawozdaniu z życia społeczno-politycznego, a konieczne są odrębne zestawienia. Ostrożny szacunek liczby ofiar starć z policją w latach 1930-1935, których przyczyną był spór polityczny bądź względy społeczno-ekonomiczne, oscyluje wokół 170. Podobne badania należałoby przeprowadzić dla drugiej połowy lat 30., ale już liczba ofiar strajku chłopskiego 1937 roku oraz wydarzeń w Krakowie w marcu 1936 roku i we Lwowie miesiąc później przekracza 70. Jest jednocześnie rzeczą symptomatyczną, że opinie na temat wzrastającej represyjności państwa pochodziły nie tylko, co zrozumiałe, z ław opozycji, ale i od sympatyków obozu rządzącego ${ }^{20}$.

Mówiąc o domykaniu przez administrację systemu, nie sposób nie wspomnieć o ewolucji postaw wobec procesu wyborczego - od systemowej apolityczności i bezstronności przez zaangażowanie w cuda nad urną aż po bezpośrednie żądania urzędników centrali MSW, by przez dosypanie głosów utrącić kandydaturę współtwórcy systemu, Walerego Sławka. Rozwiązania testowane przy wyborach parlamentarnych 1928 czy 1930 roku w mniejszym stopniu znajdowały zastosowanie wobec samorządu. Po ustawie scaleniowej z 1933 roku negatywny dla obozu rządzącego wynik wyborów niczego nie przesądzał - zawsze można było mianować komisarycznego burmistrza czy prezydenta.

Proces modernizacji państwa sprzyjał jego represyjności. Od końca lat 20. doskonalono system sprawozdawczości dotyczącej ruchu wywrotowego czy życia społeczno-politycznego - sprawozdania stawały się w coraz większym stopniu schematyczne, oparte na zestawieniach statystycznych. W 1933 roku wprowadzono odrębne (pierwotnie kwartalne, potem półroczne) sprawozdania $\mathrm{z}$ działalności polskich organizacji społecznych. W drugiej połowie lat 30 . zostały wyodrębnione raporty dotyczące przeprowadzonych konfiskat prasowych. Sprzyjało to jednocześnie lepszemu zorientowaniu się w realnych zagrożeniach dla państwa i obozu rządzącego, a z drugiej strony stanowiło coraz lepiej zorganizowaną machinę inwigilacji obywateli.

Zgodnie z dotychczasową praktyką sprawozdawczość wykorzystywała nie tylko biały wywiad, ale także sieć informatorów i konfidentów rekrutujących się zarówno spośród czołowych osobistości życia lokalnego, jak i szeregowych działaczy partyjnych. Szczególną uwagę poświęcono przy tym funkcjonowaniu partii komunistycznej ${ }^{21}$. Agentura ulokowana w strukturach ruchu ludowego była na tyle precyzyjna,

19 A. Próchnik, Pierwsze piętnastolecie Polski niepodległej, Warszawa 1983, s. 346.

${ }^{20}$ Z. Moraczewska, Listy do siostry 1896-1933. Dziennik 1891-1895 (1950), wstęp i oprac. J. Dufrat, P. Cichoracki, Łomianki 2018, s. 732-733.

${ }^{21}$ W. Kozyra ocenia, że w 1935 r. na 8-10 członków KPP przypadał jeden agent lub informator organów podległych ministrowi spraw wewnętrznych, przy czym proporcja ta nie obejmuje agentury Oddziału II Sztabu Głównego; W. Kozyra, op. cit., s. 542. 
że pozwalała na dobrą orientację w kierunkach polityki SL już w pierwszej połowie lat 30. Zbierane w ten sposób informacje, sortowane w kartotekach prowadzonych w starostwach powiatowych, miały być wykorzystane między innymi przy ewentualnym unieruchomieniu w stanie zagrożenia wybuchem wojny czy strajkiem generalnym $^{22}$. Warto przy tej okazji zwrócić uwagę, że fakt prowadzenia wspomnianych kartotek nie był przez współczesnych traktowany jako coś normalnego, skoro Komisja do zbadania klęski wrześniowej pytała o nie, a indagowani byli starostowie ostrożnie potwierdzali, że były one wykorzystywane do inwigilacji opozycji ${ }^{23}$.

Czy ten system działał? Zazwyczaj tak, ale do końca II RP zdarzały się przypadki zajść, których można by uniknąć, gdyby administracja w porę zareagowała (niekoniecznie drastycznie czy represyjnie) ${ }^{24}$. Zawodził na ogół człowiek i zbieranie coraz większej ilości informacji nie rozwiązywało problemu. Warto pamiętać, że przypadki, w których system szwankował, prowadziły do sytuacji, gdy administracja traciła na okres kilku dni lub tygodni kontrolę nad obszarami wielkości powiatu bądź większymi.

Omawianemu zjawisku sprzyjała nie tylko modernizacja, ale i unifikacja. W tych kategoriach można rozpatrywać jednolitą dla całej Rzeczypospolitej regulację, jaką był dekret prasowy z 21 XI 1938 roku. Została ona wykorzystana do zaostrzenia kontroli nad wydawnictwami, choć swoiste apogeum represji nastąpiło kilka tygodni wcześniej w związku z wyborami parlamentarnymi (tzw. biała niedziela z 6 XI 1938 r.), kiedy to żadne niezależne od rządu czasopismo nie uniknęło konfiskaty ${ }^{25}$.

Można się zastanawiać, czy tego typu represje były dotkliwe z punktu widzenia przeciętnego obywatela. Warto jednak pamiętać, że masowość partii w II RP (także opozycyjnych) była zdecydowanie większa niż współcześnie. A tam, gdzie działalność stricte polityczna nie wchodziła w grę, niekoniecznie musiała budzić entuzjazm na przykład administracyjna presja na organizowanie społeczeństwa czy rygorystyczne przestrzeganie przepisów sanitarnych.

Warto pamiętać, że opresyjność systemu bywała dotkliwa także dla samych urzędników. Przemysław Olstowski znakomicie opisał kwestie związane z istnieniem podwójnego systemu zarządzania administracją, przepływu pieniędzy pozwalającego na ich pompowanie do prorządowych organizacji społecznych i politycznych ${ }^{26}$. Ponieważ polecenia wydawane $\mathrm{w}$ trybie niejawnym miały być albo niszczone, albo zwracane do województwa, w obawie o swoją skórę (dodajmy, niebezpodstawnie

22 J. Mierzw a, Starostowie..., s. 443-444.

${ }^{23}$ Instytut Polski i Muzeum imienia Generała Władysława Sikorskiego w Londynie (dalej: IPMS), Ministerstwo Sprawiedliwości, sygn. 5.39, Protokół przesłuchania Stanisława Porembalskiego, Londyn, 10 IV 1941 r., k. 27-28.

${ }^{24} \mathrm{~W}$ tym sensie przychylałbym się do argumentacji dotyczącej aresztowań brzeskich jako środka zapobiegającego masowemu rozlewowi krwi, do którego miałoby dojść 14 września 1930 r. podczas planowanych przez Centrolew manifestacji. Patrząc na determinację ludowców np. w 1933 r. w zakresie podniecaniu nastrojów, scenariusz ten był wielce prawdopodobny; W. Pobóg-Malinowski, Najnowsza historia polityczna Polski, t. II, 1914-1939, cz. II, s. 716-717.

${ }^{25}$ A. Paczkowski, Prasa polska w latach 1918-1939, Warszawa 1980, s. 13-16; W. Kozyra, op. cit., s. 563.

${ }^{26}$ P. Olstowski, Procesy ,starościńskie”..., passim. 
w kontekście procesów starościńskich na Pomorzu) starostowie, przed oddaniem, fotografowali je na własny użytek ${ }^{27}$.

Mówiąc o opresyjności państwa, należy pamiętać, że nie była ona celem samym w sobie, a rządzący w warunkach systemu autorytarnego robili wiele, by zyskać sympatię społeczeństwa. Minister Składkowski, dokonujący inspekcji w najdalszych regionach kraju, terroryzował podległych sobie urzędników przede wszystkim ze względu na stosunek do obywatela - godziny otwarcia starostwa, tryb posłuchań. Inna rzecz, że ewentualną sympatię społeczeństwa łatwo tracił przez nakaz budowy latryn czy akcję bielenia płotów... Nie inaczej zresztą było z wojewodą poleskim Kostkiem-Biernackim, który przebierał się za chłopa, by osobiście sprawdzić, jak działa administracja czy policja, oraz krytykował egoizm i uprzywilejowaną pozycję poleskiego ziemiaństwa, lepiej traktowanego przez skarbówkę czy sądownictwo niż Poleszucy ${ }^{28}$. Także minister spraw wewnętrznych Marian Zyndram-Kościałkowski w lutym 1935 roku mógł żądać od podległych urzędników ułatwiania życia obywatelom jako celu zgodnego z interesem państwa, a kilka miesięcy później zapowiedzieć w exposé zacieśnienie współpracy ze społeczeństwem ${ }^{29}$. Jednakże wydarzenia w marcu-kwietniu 1936 roku w Krakowie i Lwowie raczej stanowiły dowód, że pod względem stosunku do obywatela, jeżeli możemy mówić o zmianie, to niekoniecznie była ona dobra... Brak mechanizmów demokratycznych spowodował, że wytworzył się system rządzenia państwem ponad społeczeństwem. Podejmowane przez rządzących i urzędników, niejednokrotnie z najlepszymi intencjami, decyzje nie cieszyły się poparciem społeczeństwa ${ }^{30}$. Wpisywało się to w plastycznie przedstawioną przez Hausnera koncepcję urzędnika, który ma służyć obywatelowi, ale obywatel, mimo że płaci podatki, nie ma prawa żądać od urzędnika czegokolwiek ${ }^{31}$.

Opisywane powyżej działania nie były zatem efektem sadystycznych skłonności rządzących, a swoistym mechanizmem obronnym włączonym w reakcji na przeobrażenia w postawach społecznych czasu wojny, ale nade wszystko odpowiedzią na stan permanentnego zagrożenia bezpieczeństwa wewnętrznego, ,stanu podgorączkowego", w którym II RP funkcjonowała od swego zarania aż po kres. Jako cel funkcjonowania administracji publicznej jawiło się dążenie do zachowania jej całości i suwerenności Polski, podczas gdy w innych przypadkach na pierwszym planie można było stawiać interes obywatela. Inna rzecz, że faktyczne zagrożenie ze strony ruchu komunistycznego często stanowiło swoiste słowo klucz, wyjaśnienie wszelkich form niezadowolenia z rządzących.

${ }^{27}$ IPMS, Ministerstwo Sprawiedliwości, sygn. 5.39, Protokół przesłuchania Mieczysława Seydlitza, Londyn, 21 IV 1944 r., k. 18.

${ }_{28}$ Archiwum Akt Nowych w Warszawie, Ministerstwo Skarbu, sygn. 5534, Pismo wojewody poleskiego Wacława Kostek-Biernackiego do Ministra Skarbu, Tajne, Brześć n.B.,. 21 XI 1932 r.

${ }^{29}$ W. Kozyra, op. cit., s. 434.

${ }^{30}$ IPMS, Ministerstwo Sprawiedliwości, sygn. 5.39, Protokół przesłuchania Tadeusza Lena, Londyn, 5 X 1943, k. 15.

${ }^{31}$ AAN, MSW dopływ III, sygn. 152, k. 3-5, Pismo dyrektora gabinetu MSW do dyrektora Departamentu II MSW, Warszawa, 31 III 1936 r. 
Jak się zatem wydaje, generalna ocena stosunku administracji do obywatela powinna być mimo wszystko nieco zrelatywizowana. Istotnym kontekstem jest tu zagadnienie bezpieczeństwa wewnętrznego i zewnętrznego, zagrożenia występującego na obu tych płaszczyznach przez cały okres międzywojenny. Stan podgorączkowy, w którym państwo się znajdowało, rodził przykre konsekwencje w relacjach z obywatelami, a postępujące procesy modernizacyjne sprawiały, że państwo w swej opresyjności stawało się coraz bardziej skuteczne. Przysłużyło się temu także utożsamienie struktury państwowej z organizacją administracji, postrzeganie społeczeństwa w kategoriach tworzywa (postawa taka była tym bardziej typowa, im o niższych instancjach administracji mówimy).

Jeżeli przyjrzeć się racjonalności i postępowości pewnych rozwiązań w II RP, zasługują one na wysokie, pozytywne noty. Administracja wykazywała, nawet na tle państw o XIX-wiecznych tradycjach własnego aparatu, dużą sprawność. Z niedostatkami spotkamy się przede wszystkim w tych obszarach, gdzie potrzebne były pieniądze, choć należy podkreślić, że trudności budżetowe nie stanowiły dla rządzących po maju 1926 roku okoliczności uniemożliwiających modernizację i unifikację. Co więcej, jak się wydaje, właśnie względy oszczędnościowe były dodatkowym bodźcem przyspieszającym dokonywanie zmian.

Rzecz jasna, nie uniknięto pewnych błędów, ale były one powszechne wśród państw europejskich tego czasu, działających przy tym w niepomiernie korzystniejszych warunkach niż rząd polski - tak należy oceniać na przykład nieopanowaną nadprodukcję aktów prawnych. Pojedyncze błędy urzędników były znane władzom centralnym, które starały się im zaradzić. Jak się jednak wydaje, to, że cała ta machina powstała $\mathrm{w}$ biegu, powodowało, iż o ile poszczególne rozwiązania były sensowne i wydajne, o tyle całość konstrukcji przytłaczała nie tylko społeczeństwo, ale $\mathrm{i}$ trybiki funkcjonujące w tej machinie. Przytłaczała zresztą w dosłownym tego słowa znaczeniu: poza urzędami wojewódzkimi i starostwami pod koniec II RP istniało 10 urzędów w pierwszej instancji i 16 w drugiej instancji. W 1938 roku 450000 funkcjonariuszy publicznych (łącznie z samorządowcami czy zetatyzowanymi organizacjami społecznymi) wraz z rodzinami stanowiło 5,6\% ludności, a 14,3\% ludności nierolniczej. Jeżeli dodać do tego emerytów państwowych i samorządowych oraz zawodowych wojskowych, to okaże się, że na jednego funkcjonariusza publicznego pracowało 9 reprezentantów ,produktywnych” grup społecznych ${ }^{32}$.

Brakowało refleksji nad całością systemu. Dobrze ujął to po kilku latach jeden z uczestników tych wydarzeń:

$\mathrm{Na}$ ogół we wszystkich komisjach usprawnienia i specjalnych ciałach rządowych, mających naprawić administrację postępowano tak, jak postępuje technik, który wysila swój umysł nad udoskonaleniem machiny wykonującej pracę przesypywania piasku z kupki na kupkę. Zagadnieniem było jak szybko i jakim kosztem przesypie. Rzadko interesowano się problemem, w jakim stopniu i dla kogo potrzebne jest sypanie kupek piasku ${ }^{33}$.

32 J. S u s ki, Rzeczpospolita Polska. Organizacja administracji publicznej, Londyn 1942, s. 75.

33 Ibidem, s. 94. 


\section{BIBLIOGRAFIA}

\section{Źródła archiwalne}

Archiwum Akt Nowych, Ministerstwo Skarbu.

Archiwum Akt Nowych, Ministerstwo Spraw Wewnętrznych.

Instytut Polski i Muzeum im. Generała Władysława Sikorskiego w Londynie, Ministerstwo

Sprawiedliwości.

\section{Źródła drukowane}

„Dziennik Ustaw Rzeczypospolitej Polskiej” 1937.

\section{Wspomnienia}

Mor a c zew s k a Z., Listy do siostry 1896-1933. Dziennik 1891-1895 (1950), wstęp i oprac.

J. Dufrat, P. Cichoracki, Łomianki 2018.

Próchnik A., Pierwsze piętnastolecie Polski niepodległej, Warszawa 1983.

Wit o s W., Moje wspomnienia, cz. II, do druku przygotowali i przypisami opatrzyli E. Karc zewski, J.R. Szaflik, Warszawa 1990.

\section{Opracowania}

Dziadzio A., Mataniak M., Namiestnictwo galicyjskie (1854-1914). Organizacja i zadania, „Krakowskie Studia z Historii Państwa i Prawa” 2018, nr 1, s. 137-167.

H a u n e r R., Pierwsze dwudziestolecie administracji spraw wewnętrznych, Warszawa 1939.

Kozyra W., Polityka administracyjna ministrów spraw wewnętrznych Rzeczypospolitej Polskiej w latach 1918-1939, Lublin 2009.

Male c J., Male c D., Historia administracji i myśli administracyjnej, Kraków 2003.

Mi elcarek A.J., Podziały terytorialno-administracyjne II Rzeczypospolitej w zakresie administracji zespolonej, Warszawa 2008.

Mierzwa J., Starostowie Polski międzywojennej. Portret zbiorowy, Kraków 2012.

Mierzwa J., Wkład Galicji w niepodległość Polski [w:] Drogi do niepodległości narodów Europy Wschodniej 1914-1921, red. D. Mich a luk, Ciechanowiec 2018, s. 24-37.

Mi erzw a J., Wotyński układ korupcyjny na tle przestępczości urzędniczej w Drugiej Rzeczypospolitej [w:] Margines społeczny Drugiej Rzeczpospolitej, red. nauk. M. Ro dak, Warszawa 2013, s. 85-102.

Olstowski P., O potrzebach badań nad procesami modernizacji społecznej na ziemiach Polski zachodniej w XIX $i$ w początkach XX wieku [w:] W kręgu dwóch kultur. Społeczeństwo polskich ziem zachodnich $w$ XIX i XX stuleciu, red. S. Wierzchosławski, A. Niewęgłowska, T. Krzemiński, Toruń 2017. 
Ols tow ski P., Procesy „starościńskie” w województwie pomorskim w latach 1936-1937. Polityka obozu rzadzacego i niejawne mechanizmy władzy na szczeblu powiatu $w$ pierwszej połowie lat trzydziestych w świetle kilku procesów karnych, Warszawa 2014.

Paczkow ski A., Prasa polska w latach 1918-1939, Warszawa 1980.

P aruch W., Myśl polityczna obozu piłsudczykowskiego, Lublin 2005.

Suski J., Rzeczpospolita Polska. Organizacja administracji publicznej, Londyn 1942.

Tarnowska A., Z dziejów unifikacji administracji w II Rzeczypospolitej. Rola przepisów pruskich, Torun 2012.

Witkow sk i W., Historia administracji w Polsce 1764-1989, Warszawa 2012. 